\title{
LA CIUDAD COLONIAL Y SUS TEXTUALIDADES CONTEMPORÁNEAS: EL COLOR BLANCO EN POPAYÁN. UN ESTUDIO DE SEMIÓTICA CULTURAL URBANA ${ }^{1}$
}

\section{THE COLONIAL CITY AND ITS CONTEMPORARY TEXTUALITIES: WHITE COLOR IN POPAYÁN}

\author{
Por: \\ Felipe García Quintero \\ Doctor en Antropología \\ Profesor Titular, Departamento de Comunicación Social \\ Universidad del Cauca, Colombia \\ fgq1973@gmail.com
}

Resumen: La valoración crítica que desarrolla esta reflexión se realiza mediante una aproximación interpretativa de la textualidad simbólica encarnada en la metáfora urbana del color blanco, cuya polisemia nominal da imagen a la ciudad de Popayán. Con ello se intenta, a su vez, situar una tentativa revisionista del estatuto cultural de la ciudad colonial. La interpretación que surge de ello atiende entonces a la semántica del color, a partir de pensar los significados semióticos desde una valoración del espacio urbano como región moral; ejercicio que procura interrogar el estatuto social y los imaginarios jerarquizados de la gramática arquitectónica mediante la crítica de los dispositivos simbólicos del poder institucional, heredados de la tradición religiosa hispana.

Palabras claves: Cronotopía urbana, identidad cultural, estatuto colonial, capitalismo.

Abstract: Critical appraisal developing this reflection is done through an interpretive approach of symbolic textuality embodied in the urban metaphor of the color white, whose nominal polysemy gives image to the city of Popayán. This is intended, in turn, to put a revisionist attempt of the cultural status in the colonial city. The interpretation that emerges from it, addresses then the semantics of color, from thinking about semiotic meanings from a review of urban space as moral region; it means seeking to interrogate the social status and hierarchy imaginaries of the architectural grammar by criticizing symbolic devices of the institutional power, inherited from the Spanish religious tradition.

Keywords: Urban Cronothopy, cultural identity, colonial status, capitalism. 


\section{Introducción}

Popayán es llamada la ciudad blanca de Colombia. Dicho apelativo nace por el predominio del color blanco en la arquitectura del centro histórico, cuya configuración se remonta al siglo XVI, cuando la ciudad fuera un importante eje del poder colonial español, ejerciendo por entonces una labor civilizatoria destacada en su entorno, tanto a nivel económico como político y cultural.

Luego de trescientos años de dominio, en condición de colonia española, surge el espíritu emancipador americano. Y en tantos escenarios de confrontación armada que suscita la lucha libertaria Popayán juega un rol protagónico por prestar sus vastos territorios a las batallas, entregar riquezas y sacrificar lo mejor de su intelectualidad. De esa realidad queda una memoria idealizada de fortunas saqueadas y mártires de panteón, que bien sirve de referencia histórica a la ciudad actual para evocar los antiguos poderes y, con ello, reafirmar la identidad cultural contemporánea. Esto en el sentido que el pasado adquiere para el presente, al significarlo, y por ser además la fuente de distinción y prestigio sociales, aún vigentes en su estamento tradicional.

El color blanco de la arquitectura monumental constituye, pues, una marca simbólica que sirve de principal referente identitario de Popayán, al punto de convertirse en el signo esencial de la imagen con la cual la ciudad afirma sus creencias y prácticas espirituales, y por este principio autodefine su patrimonio arquitectónico, reconocido además por su valor histórico ecléctico en la publicidad comercial y turística de afiches, postales, pinturas y artesanías que representan, con sus modelos y motivos, el ser mismo de la ciudad blanca.

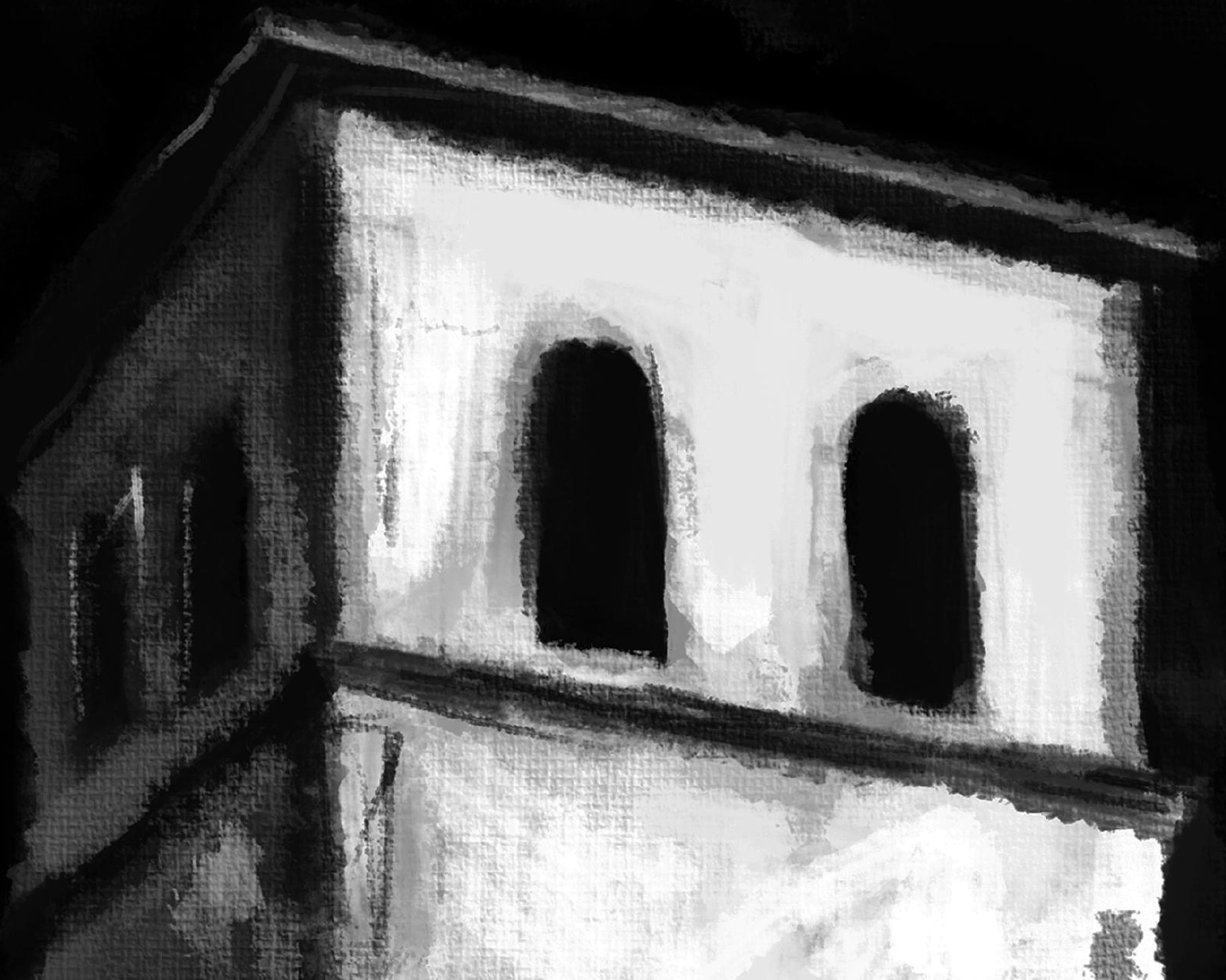


Adicional a la materialidad física urbana, la tradición literaria de Popayán soporta por igual esta construcción como discurso cultural vivo, que ve reproducida la imaginería colonial en el lenguaje cotidiano y el paisaje citadino, en cuanto estilo de una estética expandida fuera de las fronteras históricas del casco viejo. Todos estos elementos constituyen una gramática urbana que enuncia con sus signos y símbolos la actualidad nostálgica del ayer en el presente, cuyo principal dispositivo simbólico es la fotografía del centro arquitectónico monumental viejo y el entorno natural de las colinas y el río Molino que la cruza.

La valencia múltiple de lo blanco en la ciudad no sólo da cuenta del cromatismo de la arquitectura como referente espacial del territorio, por su virtud homogéneo y hegemónico de una matriz ideológica de poder, que ha polarizado a Popayán como centro opulento de significado cultural, en contraste con unas periferias innominadas y desprovistas de imagen propia al carecer de representaciones que nombren y legitimen su realidad social, mediante construcciones de signos textuales. Estos elementos dicotómicos configuran la diglosia social que lleva a la ciudad a hablar dos lenguas, una con reconocimiento social y otra relegada a la condición marginal de las prácticas culturales sin representación como llegan a ser las artes juveniles de hacer ciudad (cfr. de Certeau, 2000).

El color blanco se constituye en un símbolo polivalente dentro del sistema cultural con el cual Popayán se afirma y es reconocida por sus habitantes. En la reconfiguración que se ofrece a continuación lo blanco no es un color sino una moral; además, por supuesto, de significar también una marca de identificación social que otorga identidad al espacio urbano.

\section{Persistencia espacial del centro histórico}

La matriz urbana del trazado colonial en damero, de la cual Popayán se desprende irregular hacia otros lugares, ha permanecido inalterada desde su fundación por Sebastián de Belalcázar el 13 de enero de $1537^{2}$. Ninguno de los tantos terremotos, por ejemplo, ha hecho desplazar el centro histórico del lugar que hoy sigue ocupando en la ciudad. De esa persistencia espacial de la ciudad durante más de 450 años interesa resaltar el papel del urbanismo colonial arquitectónico, remozado muchas veces a imagen y semejanza del ayer hispano como lugar hegemónico de producción cultural, y en virtud de ser este escenario el otorgante del mayor sentido de la identidad ciudadana hoy.

Comprendemos el procedimiento que ha permitido conservar esta propiedad, en razón de la correspondencia entre la organización espacial del territorio original español y el orden social jerárquico allí asentado, reproducido ahora mediante el procedimiento de copia de su estilo y estética, que regula y determina la totalidad urbana bajo la polarización de sus fronteras a través, principalmente, de la definición de una identidad urbana esencial y pura de origen hispano religioso, que constituye la marca colonial de rostro único, memoria exclusiva, lengua castiza, escritura histórica de asepsias y voz univalente, de cuyos acentos y ritmos es acallada la diferencia y la diversidad sociales que la pueblan de voces y hablas callejeras. 


\section{Organización espacial colonial y orden social contemporáneo}

Por efecto del pasado la ciudad actual establece el sector colonial como un eje de poder material y simbólico. La primera dimensión se debe al legado de la historia y las nuevas incorporaciones patrimoniales realizadas durante las últimas décadas, afines de aquel patrón arquitectónico convertido ahora en estilo y estética expandidos. Adicional, por supuesto, a la dinámica urbana comercial y administrativa de servir de acceso principal a bienes y servicios. Lo segundo se da porque el centro histórico es el lugar del cual emanan los principales relatos culturales, los que adquieren mayor significado y arraigo en sus habitantes a través del tiempo, como es el caso particular de la ritualidad religiosa. Todo lo anterior obedece a tres motivos primordiales: 1 . Las más importantes instituciones de tipo civil, comercial, espiritual y cultural, tienen asiento en este territorio ${ }^{3}$; 2 . Cada año la puesta en escena de la Semana Santa, sin duda el principal de los rituales urbanos, transcurre por las calles del centro histórico, actualizando con su recorrido el sentido de pertenencia y afirmando, a su vez, los valores de la tradición cultural hispánica; y 3. La imagen de la ciudad es tomada del rostro colonial, pues se trata de una construcción imaginaria que encuentra respaldo real tanto en los puntos anteriores como en la arquitectura misma, cuyo discurso y relato encuentra también su razón y sentido sociales en los símbolos de un entramado antropológico complejo.

En cuanto a la determinación espacial del territorio, esta condición de la ciudad impone al habitante la dicotomía moral de tener consigo un centro positivo versus unas periferias de valencias negativas, configurada mejor bajo la categoría expuesta de diglosia urbana. Miremos, de paso, cómo opera este fenómeno a nivel territorial:

El sector colonial es asumido por el payanés raizal como el lugar de la hegemonía cultural, pues la autodefinición del mismo por la historia es refrendada de muchas maneras, principalmente, mediante procedimientos de tipo simbólico, como la reproducción de la gramática colonial, por ejemplo, a través de las fotos y la iconográfica de sus imágenes arquitectónicas, que sirven al propósito del anuncio publicitario turístico, o incluso de evocación familiar y personal, cuando se las instala en el interior de instituciones, establecimientos o en salas de recibo de casas de habitación, para exhibir con orgullo los valores que representan el patrimonio material de templos, claustros, torres o puentes. Otra forma de reproducción de este discurso es la réplica a escala de algunas edificaciones emblemáticas, incluso dentro de las fronteras mismas del centro histórico, tal y como ocurrió hace pocos años con la creación del rincón payanés, ubicado al oriente del casco viejo, en el sector de la antigua piscina municipal del sector de Tulcán. Igual proceder aplica ahora en los lotes baldíos que dejó el terremoto del año 1983, pues del color cenizo de las fachadas vetustas surgen nuevas edificaciones que simulan el estilo viejo y antiguo; es decir, colonial, y de este modo replican las formas arquitectónicas de la ciudad histórica, con un carácter de antigüedad que pocas construcciones conservan y, por ende, acogen el aura de sacralidad que emana de esta categoría. 
La importancia de todo esto es señalar el procedimiento con el cual la ciudad expande la idea de centro de poder hacia sus fronteras, incorporando para sí otros territorios, con lo cual se fortalece aún más dicha hegemonía. Otro caso lo constituye la denominación lingüística de lo urbano reiterada en la palabra "colonial". Algunas edificaciones nuevas son bautizadas con este apelativo que da continuidad al relato histórico hispano. Bajo este sema cultural el imaginario tradicional de la ciudad coloniza y anula, casi en su totalidad, cualquier atisbo de modernidad arquitectónica, incluso de aquellos lugares que efectivamente están dentro de una temporalidad y espacialidad distintas como lo es el Centro Comercial Campanario, cuyo nombre guarda una relación filial con el imaginario tradicional ${ }^{4}$. A nivel de las prácticas rituales, la celebración de la Semana Santa es el caso emblemático de mayor afirmación del espíritu hispano occidental, con el cual la ciudad restaura y revitaliza su aura colonial de ciudad de tradiciones.

Mientras todo esto ocurre en el centro histórico, las regiones próximas y lejanas del casco viejo, que vienen a ser la vastedad restante de la ciudad misma de ya casi 300 barrios, se mantienen en la mudez, pues resultan innominadas por la tradición hispana que las sitúa en la franja cultural de lo subalterno, bajo la disputa simbólica de una lucha de sentido por el reconocimiento de una identidad propia. Las representaciones simbólicas

realizadas por sujetos orgánicos u actores sociales externos, como son algunos videos argumentales, narraciones literarias o poéticas ${ }^{5}$, carecen de legitimación social o sufren de la estigmatización de lo marginal, al ser considerados por el estatuto cultural como productos que adolecen de autoridad estética. Este fenómeno agrava la falta de afirmación institucional de los sectores populares, objeto de una mirada prejuiciada que tiende al estereotipo social. Prueba de ello es que, además de la reinante imagen urbana del centro tradicional, las prácticas rituales de las periferias son también desconocidas e incluso reprimidas en sus aspectos fundantes, como es el caso de la sanción impuesta al agua en las Fiestas de Pubenza, un incipiente carnaval, cuya debilidad principal es la poca cohesión que suscita en la ciudadanía. Este fenómeno revela que la cultura urbana se asienta en la solemnidad y se funda en el sentido trascendente religioso y no en el carácter mismo de la fiesta pagana.

La orientación geográfica del centro establecida hoy en la ciudad da cuenta de un escenario privilegiado por el legado histórico, favorecido por los estamentos institucionales actuales, y amparado con fervor y celo en el imaginario urbano tradicional de las 
prácticas rituales religiosas y el silencio contemplativo de la divagación nocturna, lo cual deriva, en consecuencia, en una construcción privilegiada del territorio por ser jerárquica y estratificada su valoración moral, cuyo uso hace a Popayán dueña de un dispositivo de control social efectivo a la hora de pensar el ser urbano ancestral, separado de los sectores populares.

Tenemos entonces que considerar el centro histórico y el sector colonial como locus de enunciación de instancias de poder cultural. Aquel esquema binario de centro/periferia, borrado en su dicotomía divergente en otras ciudades colombianas, pareciera encarnar ahora como reproducción actualizada de la estructura de poder colonial, que escindiera los sectores urbanos en privilegiados y excluidos, ahora con la presencia de actores sociales como los jóvenes urbanos en moratoria social y los vendedores informales y estacionarios del comercio informal que han desestabilizado este esquema binario autocontenido y puesto en crisis el modelo de su representación hermética, refractaria del contacto cultural y las articulaciones sociales. No se trata ya del legado en uso de aquel estatuto peninsular que ordenara idealmente el conglomerado heterogéneo de la sociedad hispanoamericana bajo las categorías de República de españoles y otra, apartada, de indios. ${ }^{6}$

\section{Popayán: arcadia colonial o ciudad de Dios}

El siguiente paso consiste en determinar un asunto relevante de esta aproximación crítica, como es el sentido que comporta la tradición hispana para el presente. Un elemento de ayuda enunciado estima considerar la arcadia como el imaginario urbano vigente en Popayán. Valga recordar que esta noción hace referencia a un lugar sin muerte, desigualdades o injusticias, y, por ende, simboliza un reino pleno de felicidad, armonía y paz. Los dispositivos que sirven a este propósito de pensar así la ciudad han sido tomados de la tradición cultural religiosa y de su historia social como de la relación entre naturaleza y arquitectura que resuelve la vieja antinomia civilización/barbarie, por lo cual la ciudad se percibe y concibe como un señorío elegido por Dios para ejercer su reinado entre los hombres ${ }^{7}$. Lo anterior se establece como principio de verdad incontrastable, pues el pasado de prestigio, riqueza y ostentación resulta cierto cuando se trata de situar el lugar que Popayán ocupó en el mundo colonial como centro civilizatorio y enclave económico importante para la geopolítica de transculturación española en América, a través de la lengua castellana y la religión católica (Cfr. Rama, 1984). Gracias al cumplimiento de esta misión, la villa recientemente fundada adquiere pronto el título de ciudad noble; que desde entonces (1558) exhibirá con méritos siempre evocados, al seno del cual nacerá también el mito presente de señorío feudal instaurado por una sociedad hidalga para el descanso y el cultivo del espíritu sin esfuerzo físico, y hoy autonominada con el distintivo de ciudad universitaria o del conocimiento, en clara prolongación histórica, del carácter letrado colonial. 
Esto fue posible porque de la ruina material y humana que trajeron las guerras de independencia al reino de una América hispana, negra, indígena y mestiza, revelada contra las leyes borbónicas que marginaban del poder a la élite criolla, la Popayán apocada por la penuria y la muerte pasa a las manos pulcras pero ociosas de una sociedad local que hizo suyo el sueño hidalgo español de ostentar una distinción sólida en recursos que no requería al parecer del trabajo propio para mantenerse en pie y sobrevivía, en cambio, del esfuerzo ajeno de esclavos e indígenas a su cargo. Una realidad creada sólo por el efecto ilusorio de la invención mental que procuraba el poder del mito hidalgo - hasta ahora el capital más apreciable del patrimonio cultural de la ciudad como legado histórico--, cuyo mayor proyecto consistió en hacer verosímil la ficción de creer como distinto lo que en realidad se era: unas exiguas castas empobrecidas, dueñas sí de un refinamiento intelectual, una devoción religiosa y una sensibilidad artística únicas y exclusivas para hacer de su fábula una realidad concreta (Cfr. Romero, 1976).

De ello surge también la idea del pasado como fuente de toda verdad actual, y donde hoy tiene asiento la imaginería de la Popayán contemporánea que se apropió su historia y la convirtió en ese relato sin discusiones hoy conocido, el cual no admite contradictores. La nostalgia por esa historia de leyendas acentúa el valor del mito de Popayán como arcadia colonial o ciudad de Dios que resulta inmarchitable, a fuerza de repetir su propio relato en imágenes visuales como la foto arquitectónica y verbales de los relatos fundacionales que escribieran ilustrados como Jaime Arroyo (1955), o bien con las ceremonias sacras y en la textualidad monumental, tal y como se procura mostrar mediante la aproximación interpretativa de la metáfora urbana del color blanco.

\section{Cultura colonial gramaticalizada y textualizada}

El grado actual de inventiva puesto al servicio de prolongar la infancia colonial de la ciudad, hasta el punto pernicioso del autoplagio, como lo prueban los casos de la arquitectura convertida en estilo de una gramática y en la estética de un discurso al servicio del imaginario hispánico contemporáneo, se nos antoja revelador de un complejo mayor del que aqueja a Peter Pan. La inquietud que surge respecto de este personaje literario del inglés J. M. Barrie (1987), quien se niega a crecer y abandonar la infancia, es: ¿si por temor al cambio Popayán se resiste a hacerlo también y prefiere regocijar su existencia limitándola al pasado de un pasado opulento, de esplendor y gloria, hoy ausente o ya perdido? No obstante, los agentes de transformación cultural como son la expansión urbanística y el crecimiento demográfico y la intensificación de los flujos migratorios durante las tres últimas décadas, al Popayán tradicional le son suyos, sin objeción, el patrimonio arquitectónico heredado y protegido por el reconocimiento monumental de una $l y^{8}$; sumado a ello las prácticas espirituales y el refinado humor intelectual y aristócrata que ha encarnado en imaginario de prestigio por décadas, en cuanto destreza oral y cotidiana de generaciones que reproducen la leyenda picaresca de figuras públicas y artísticas que no excluyen del repertorio a personajes populares. Esto es parte sustantiva del ser urbano letrado, aspecto que bien encuentra en el ejercicio literario de la representación poética y narrativa una ciudad deificada en éxtasis y agonía durante no menos de cuatro siglos (Cfr. García, 2006). 
Asimismo, otros hechos culturales hacen también de Popayán un bastión de la hegemonía hispana colonial; carácter que valga notar le es propio a la ciudad, en el sentido de autenticidad que proporciona la incorporación de elementos exógenos re-significados dentro del universo local, propio de la estética barroca hispanoamericana. Lo referido elude a la ritualidad simbólica religiosa, la publicidad urbana del turismo que promueve el acervo patrimonial céntrico, y desde su fundación el título de ciudad letrada, por lo cual la condición colonial no supone herida o trauma identitario alguno, tal y como podría pensarse desde una perspectiva culturalista o decolonial. Sin embargo, sobre este asunto que proporciona carácter a la identidad cultural de Popayán, se estima el legado patrimonial de bienes materiales y simbólicos que hace que el plus de valoración histórica de la ciudad hispana sature la realidad actual con múltiples referencias de lo pasado, al punto de hacer del presente un estado de mudez continua frente a sus propios valores que resienten el no reconocimiento ni la legitimación social, quizá a pensar a través de un ejercicio de diálogo y formación educativa; es decir, espacios donde sea posible reflexionar acerca de los elementos y fenómenos posmodernos de lo multi, lo pluri, lo trans, y lo hetero de las identidades sociales contemporáneas en constante pugna y permanente redefinición.

No por ello la heredad de lo hispánico colonial deja de ser para Popayán un discurso fundante de su identidad urbana contemporánea, esto encarnado en el hecho concreto de variadas prácticas culturales gramaticalizadas y textualizadas a nivel cotidiano como las mencionadas antes, las cuales alcanzan un poder de afirmación único, ejercido de manera reiterada y enfática para dar sentido de pertenencia, cohesión y trascendencia, tal como sucede de otro más totalizador con la celebración de la liturgia católica ${ }^{9}$ y, desde hace unas décadas, con el color blanco predominante en el centro histórico, resultado de la simbólica religiosa de representar con esa textualidad valores de pureza y virtud, cuya exaltación de lo inmaculado y su consecuente efecto purificador pretende superar la embestida del pecado; lo cual privilegia, en suma, el legado clerical arquitectónico, tan característico del ambiente conventual de la ciudad de hoy.

\section{Lo imaginario y lo simbólico en la metáfora urbana del color blanco}

En virtud de considerar lo imaginario como potencia creadora de sentido que utiliza las formas simbólicas para manifestarse y significar la realidad, en la historia de la humanidad, afirma Cornelius Castoriadis (1982, pág.220), las imaginaciones fundamentales han sido el origen de nuestros órdenes sociales. Pensar lo imaginario, entonces, nos conduce a comprender las estructuras humanas del ser que las ordena en categorías y principios, bajo la forma de signos y símbolos. Acceder a estas elaboraciones de la cultura simbólica, en busca de dar con los sentidos profundos que esconden, es entrar en contacto con niveles de pensamiento que figuran espontáneos o arbitrarios en apariencia pero que son intencionales en realidad $y$, por consiguiente, deben ser interrogados para su interpretación social.

Por la producción simbólica que posee, en tanto institución imaginaria colonial hispana, Popayán resulta ser uno de los casos más emblemáticos de la cultura urbana en Colombia; según se anotó, la identidad payanesa se presenta bajo una configuración histórica de poder y dominio, cuya fijación espacial cotidiana está dada por la jerarquía fronteriza del territorio central polarizado en su relación con las periferias, bajo la diglosia social antes descrita. La fundante organización espacial de la ciudad hispánica de cálculo estratificador e impuesta mediante el damero colonial, signó el orden social contemporáneo; de tal suerte que la textualidad simbólica de la historia está presente hoy a través de la cultura heráldica de escudos, lozas y placas que reproducen el imaginario hegemónico de la arcadia colonial y republicana con sus signos, marcas y tatuajes. 
Dentro de ese universo textual, el color blanco se nos presenta como uno de los agentes primordiales del sentido contemporáneo de la identidad ciudadana. Por efecto de repetir su aplicación funcional arquitectónica, a modo de crear una imagen unificadora, el color blanco se convirtió en una marca urbana, al parecer, eterna e inalterable, cuyo origen sin embargo data de fechas recientes.

Hoy, esta textualidad simbólica constituye el principal referente identitario urbano, pues al identificar la ciudad la distingue del resto de las capitales del país, y proporciona, además, auto-reconocimiento, al hacer que el resto del espacio urbano sea registrado y usado como el eje central de fuerte cohesión imaginaria; razón por la cual a la ciudad toda se la designe por la propiedad cromática del blanco, sin que en verdad lo sea. Pero el color no es sólo una valencia neutra sino que constituye una marca cultural de la identidad urbana como estructura antropológica. En lo que resta de esta exposición, se procura explicar por qué, por ejemplo, el blanco es orden y por qué, además, cura. Aparte de ser símbolo también, cuyo efecto imaginario hace creer que la simetría arquitectónica responde a la armonía social. Esto ocurre cuando se interpreta su sentido de uniformidad en términos de pulcritud, seguridad o tranquilidad.

\section{Popayán, ciudad blanca}

El apelativo monocromático es una producción cultural propia del imaginario local. Por decisión de sus habitantes Popayán ha dado en llamarse "ciudad blanca". Si blanco es el rostro oficial de la ciudad y los estamentos de poder están bajo su dominio simbólico, ¿de dónde y cuándo surge la idea de este color para definir la identidad del ser urbano contemporáneo? Ante la creencia popular de lo blanco como marca o denominación de origen y signo de antigüedad histórica, cabe señalar que la ciudad sólo adopta institucionalmente esta característica a partir de la segunda mitad del siglo $\mathrm{XX}^{10}$, bajo la determinación impartida por el arquitecto Jaime Coronel Arroyo (Velasco, 2004, pág. 161).

Y a raíz de los efectos destructores del sismo de 1983, que dejó al descubierto la estructura material interna de la ciudad colonial, se ha podido evidenciar un cromatismo variado en el sector histórico, de tonos suaves, que el arquitecto Germán Téllez (1998, pág. 93) denomina ser el resultado de "una larga tradición de color aplicado, desde la época colonial, ya fuese como acentos en aleros, sófitos, marcos y contornos de vanos, zócalos y cornisas, o bien, como superficies completas en planos de muros exteriores e interiores". El mismo Téllez (1998, pág.93) informa que la procedencia histórica de aplicar esta técnica del color proviene de la cultura urbana neogranadina, cuando se empleó la cal blanca por sus propiedades de uniformidad y bajo costo, y como acabado final de enlucimiento de fachadas, junto al empleo del verde oscuro en puertas y ventanas y el negro brillante en rejas y herrajes.

Si bien el origen de la materialidad textual es histórico como práctica generalizada en la cultura colonial urbana, y así mismo la evidencia del color da cuenta de una edad reciente en su aplicación arquitectónica contemporánea, que por efecto de la pregnancia simbólica (Cassirer, 1998) las temporalidades de cada elemento no son distinguidas y separadas, sino sintetizadas e incorporadas como una totalidad única en la simbólica del color como unidad imaginaria fundante, la interpretación de lo blanco lleva a pensar este signo como metáfora religiosa de los valores de pureza y virtud del canon espiritual cristiano. 
Cuando se habla del blanco en Popayán no se hace referencia al color como a la moral que probablemente encarna y que es manifestada a través de la representación monocromática preponderante de la arquitectura central ${ }^{11}$.

La identificación de un imaginario urbano con un color podría resultar un asunto sencillo de establecer, esto si sólo se tratara de ver en el color un elemento cromático y no el símbolo de una estructura cultural compleja, como se ha empezado a revelar. De tal suerte que bajo el procedimiento simbólico, en apariencia ingenuo y sutil, de elegir un tono de color para pintar las fachadas de la arquitectura central, se esconden significados mayores del ser urbano en Popayán, lo que, a su vez, se observa en la cotidianidad ciudadana como doxa y habitus.

\section{El color blanco en Popayán: Doxa y habitus urbanos}

Se busca precisar ahora, ¿a qué obedece el predominio de lo blanco en la arquitectura central de Popayán, si es conocido ya que la persistencia histórica reside en el empleo del mismo material (la cal), mas no en el uso determinado de un mismo color? La respuesta posible es que se trata de ver en lo blanco un signo cultural desplazado de su valencia original, y convertido en una marca identitaria de la textualidad urbana contemporánea como dox $a^{12}$ de antigüedad, de tradición, y como habitus social; fenómenos que operan en el imaginario ciudadano al modo de una metáfora totalizante de la ciudad, escindida entre dos universos polares de las dos lenguas que habla la ciudad, al tiempo, antagónicas y complementarias.

El efecto aparencial del color blanco actúa en el imaginario urbano de Popayán bajo la idea adicional de robustecer el sentido histórico de la arquitectura ecléctica central, que pasa por ser considerada también auténtica en edad y original en estilo, en cuanto al valor patrimonial de las viejas edificaciones, ya restauradas o bien intervenidas en muchas ocasiones y de diversas maneras, especialmente cuando la ciudad se ha visto afectada por los terremotos. Además, la ilusión cromática de lo blanco surte un resultado real y definitivo al uniformar la diversidad arquitectónica y dar homogeneidad al centro hispánico. Esta propiedad no puede situarse por fuera de la vocación hegemónica del imaginario colonial como eje de poder. Y el color blanco es metáfora urbana en el sentido estricto de proporcionarle a Popayán la totalidad única de una sola imagen, exclusiva, pura y esencial, al patrón religioso del imaginario tradicional, con lo cual la ciudad se autodefine a sí misma y proyecta la solidez de su estética hacia las. fronteras presuntamente sin aura histórica. 
Así, la ciudad colonial, a través de sus signos y símbolos, dicta su escritura porque es el agente discursivo que enuncia el ser urbano contemporáneo de Popayán. Los íconos arquitectónicos y la textualidad simbólica de los emblemas culturales allí contenidos y significados, se constituyen en el principal referente material del ciudadano marcado por el espacio semantizado de la tradición hispánica colonial, criolla, republicana y presente. La lectura de estos signos se torna en pertenencia, a través de la experiencia vital del territorio como cotidianidad espiritual y corporal. De tal suerte que sólo cuando se logra interiorizar la ciudad en imágenes y evocar en relatos, mediante la incorporación del lugar físico en tanto espacio de la mente y el cuerpo, se la asume también como habitus.

En la perspectiva sociológica propuesta por Bourdieu (1991) situamos el centro histórico o sector colonial de Popayán como escenario simbólico donde el ciudadano adscribe su identidad de sujeto urbano a la de la ciudad tradicional. Esto entendido como elemento de incorporación del orden social "de las experiencias pasadas que, depositadas en el organismo bajo la forma de principios (schémes) de percepción, pensamiento y acción garantizan su reproducción y su constancia a través del tiempo" (Bourdieu, 1991, pág. 95). El habitus urbano local es ese vivir la historia de Popayán hecha corporeidad física y mental en la textualidad arquitectónica que habla de la ciudad como discurso y gramática vigentes para nombrar el mundo. Allí donde los estamentos y las instituciones del poder urbano pueblan el imaginario ciudadano imponiendo su visión, inscribiendo sus símbolos y encarnando una idea de la realidad con sus rituales, en tanto sistema de pensamiento exclusivo, y a través del cual lo colonial hispánico mantiene inmarchitable y renovada su fuerza de cohesión social.

El color blanco es también un signo desplazado de su utilidad inicial como insumo material, pero no por ello disminuido sino, al contrario, re-significado en su potencia máxima de dar sentido y, por tanto, significado a la identidad cultural urbana con sus atributos y valencias simbólicas, las cuales se pasa a interpretar.

\section{Propiedades y valencias semánticas del color blanco en la arquitectura del centro histórico de Popayán}

El uso del color blanco en algunas ciudades coloniales en Colombia, sostiene Germán Téllez (1998, pág. 93), se lo puede relacionar con un asunto de clases sociales diferenciadas y jerarquizadas por los signos. El ejemplo que proporciona este arquitecto lo relaciona con el vestido, pues lo blanco de las prendas revela una distinción social que hace del color un símbolo de aristocracia. Dentro de este orden de poder, agrega, el uso del cromatismo se reserva a las clases sociales "inferiores". Al respecto Alberto Saldarriaga (1985, pág. 13) sostiene también que existe un "contraste tan marcado entre el empleo del color por parte de los grupos populares y el temor a su uso en otros grupos sociales: el color se convirtió en el signo inequívoco de lo popular y, por ende, de lo vulgar; para los remilgados estamentos de la pequeña burguesía urbana y de la distante aristocracia los colorines eran claros indicadores de orígenes dudosos, de modales cuestionables". De tal suerte que el color blanco, además de ser una marca arquitectónica de la identidad urbana local, se constituye en un signo cultural de distinción y autoridad social. 
Frente a lo anterior, situamos este estudio en la línea del desplazamiento simbólico, a modo de una torsión que ha operado en las propiedades del color blanco de la arquitectura de Popayán, ya se anotó, centralizada por el imaginario colonial como imagen total de la identidad urbana contemporánea. Por ello, cabe recordar que el empleo de la cal tuvo usos paralelos y distintos al exclusivo de enlucir fachadas e interiores, pero afines a éstos, que terminaron por configurar la unidad estructural del color como región moral urbana. Según la oralidad de la memoria tradicional durante mucho tiempo la cal en Popayán estuvo destinada a ser el principal recurso medicinal para el control de infecciones y plagas de insectos como la nigua, problema muy común en otra época; por lo que el atributo textual del color blanco se convierte en un agente aséptico urbano de gran efecto catártico de males o dolencias ${ }^{13}$. Con la paulatina modernización local, esa función dejó de ser útil, pero sin haber perdido aún sus efectos sociales, antes de saneamiento ambiental, hoy de control moral.

\section{Región moral: asepsia social urbana}

Un solo ejemplo de hoy día logra explicar esta primera valencia como hipótesis de análisis interpretativo. Cada año, antes de celebrarse la Semana Santa, se encalan de blanco las paredes del centro histórico que da albergue a las procesiones; paso previo, mas ya constitutivo del ritual, que forma parte sustantiva de la purificación espiritual del cuerpo ciudadano. Esto se integra también a un procedimiento estético de higiene urbana, que busca purgar de males, culpas y pecado a la ciudad; con un efecto adicional del enlucimiento necesario, y es que la diferencia cultural de Popayán resulta abolida. Si las fachadas se limpian de voces, lenguajes, escrituras y memorias, todo aquello disonante del canon religioso de asepsia, expresados en textualidades modernas y juveniles del tipo graffitis o esténciles, por ejemplo, es porque resultan feos para el criterio moral hegemónico y, por ende, malos a juicio del imaginario colonial purista que le teme a la mancha de la diversidad social, y prefiere acoger en cambio la monocromía y univocalidad de lo homogéneo y simétrico que proporcionan los atributos del color blanco, para generar así una aparente idea de igualdad, armonía y paz, encarnado en el mito de Popayán como arcadia colonial o ciudad de Dios.

Esta construcción cultural de purgación y saneamiento es obra exclusiva del imaginario religioso occidental que simbolizó el color blanco como el signo mayor de pureza espiritual y trascendencia material ${ }^{14}$. En tal sentido, la práctica local del color es una gramática propia aprendida de un discurso mayor constitutivo, que se suma a la tradición como un eslabón particular del metarrelato de la cristiandad, aunque diezmado por la embestida posmoderna que socava sus fundamentos, no cesa en su avanzada colonizadora. En tal sentido, Popayán es un bastión efectivo de la religión católica como creencia y práctica de poder. 
Valga agregar también que frente al estatuto cultural y científico del color blanco como símbolo cromático de síntesis de los primarios y totalidad de lo distinto y serial, según Juan Eduardo Cirlot (1981, págs. 101-102), a nivel antropológico el blanco es más que un color, pues se lo ubica en relación al ascendente ejercido sobre los otros colores en tanto centralidad sagrada y fuerza de lo celeste, que encarna también como símbolo de la deidad; esto se observa, aplicado a Popayán, no en su capacidad sintética para representar la diferencia y la diversidad cultural, sino en la antítesis de expresar el silencio, de acallar la multivocalidad del habla social urbana, y de hacer de la mudez aterradora del vacío un temor humano a la totalidad teológica de la nada. E incluso, la textualidad arquitectónica de lo blanco que opera en Popayán, conduce a preguntar si no se trata también de un dispositivo de discriminación racial, dado el legado esclavista de la élite colonial, cuyos prejuicios étnicos saben florecer en el discurso político y en las actuales prácticas culturales del poder, cuyo fervor delirante por los abolengos y blasones hidalgos es una de las formas de ostentar distinción y superioridad social.

\section{Ars vacui}

A tal orientación se propone interpretar el significado social del color blanco como un arte del vacío y la negación de la diferencia que contiene la condición multicultural y heterogénea de la ciudad contemporánea, opuesta al valor grande del estilo barroco religioso de algunos templos de Popayán, que custodian y exhiben retablos, atrios, púlpitos, relicarios, caliceros, esculturas, entre otras piezas antiguas del ornamento litúrgico cristiano, hechos en madera y metal, copiosamente enriquecidos de formas y colores; sin olvidar el patrimonio de la orfebrería y ciertas piezas arquitectónicas vinculadas con la estética del horror vacui ${ }^{15}$, en su variante hispanoamericana del barroco cortesano y católico de lo sensual, monumental y decorativo (Hauser, 1976, pág.91).

No obstante, las fachadas del casco viejo en Popayán, ocupadas por el vacío simbólico del blanco como representación del silencio y tal vez de la nada, no guardan el sentido oscuro de la angustia metafísica de Pascal ante el "silence éternel des espaces infinis", sino que asimila de la poética barroca una valencia positiva hasta cierto grado, mediante la trasformación del ser en parecer, con lo cual se establece un pacto alegórico entre imaginación y realidad. De tal suerte que el procedimiento cromático funge de victorioso en cuanto hace verosímil la ficción de la gramática colonial como mito urbano de estilo y estética únicas, para simular una realidad histórica esencial, exclusiva y pura, ocultando con ello la condición ecléctica temporal y artística del patrimonio monumental, ya mencionada, levantado del suelo muchas veces por efecto de la fuerza telúrica, a imagen y semejanza de una cartografía idealizada y acaso jamás existente de aquello dado en llamar el "estilo Popayán” (Cfr. Castrillón, 1972), que se esgrime como principio rector del devenir arquitectónico central posterremoto. Lo original y auténtico, entonces, resulta ser sólo la idea de ciudad colonial, su imaginario y no su representación material del constructo artificial de edificaciones. Es comprensible el porqué en Popayán el imaginario es más colonial que la arquitectura céntrica de blancas fachadas, aleros altos y tejados marrones de barro cocido. 
Si la realidad es aparencial y puede ser objeto de mutaciones artificiales, el mundo es un teatro y la vida juego espectral, nos enseña la dialéctica picaresca. Este referente es una variante literaria del barroco popular español trasplantado a América, ya no como representación narrativa sino como práctica y experiencia de una mentalidad ingeniosa, propia de la ficción hidalga; aspecto que adquiere la categoría de legado cultural en la sociedad tradicional de Popayán. Se debe en consecuencia considerar la lógica semántica del ser y parecer en que se funda el discurso barroco picaresco, y en el cual está inscrito el imaginario urbano bajo la representación dualista del estatuto estético monumental que mantiene la diglosia social, los dos lenguajes separados de la ciudad imaginada y la vivida.

\section{Estética urbana del color blanco: El estatuto dualista analógico}

En relación profunda con las anteriores valencias, se halla una propiedad del color blanco que enfrenta a pensar la textualidad simbólica del sector colonial de Popayán bajo la dicotomía estética griega clásica, fundante del pensamiento binario en Occidente, por la cual lo bello es bueno y lo feo malo. Esta asociación maniquea de los contrarios es además un principio de analogía moral, que también separa el mundo social entre criterios divinos de verdad y humanos de mentira, con lo cual la noción estética se polariza entre aquellas formas estimadas verdaderas y lo configurado como falso o aparencial, sin ubicar un punto de equilibrio que determina la interacción de estas fuerzas ni su lucha o dé estabilidad a la contradicción que funda y niega lo heteróclito de la mixtura y la hibridación actuales.

Dentro de la lectura semiótica del color hasta el momento expuesta, el estatuto dualista analógico es un atributo estético que encarna en un problema de discriminación social, adicional al efecto de jerarquización y estratificación espacial de las fronteras simbólicas que crea la relación centro/periferia como cartografía física, bajo la imagen pública del eslogan publicitario y turístico de "Popayán ciudad blanca". Se trata de la operación que viene signada por el efecto imaginario de fundar regiones morales en torno al territorio, según la textualidad urbana, y cuyos signos hablan de una ciudad buena, la ungida de blanco, diferenciada de una mala, la sin color que tiene todos los tonos de la diferencia cultural. El resultado es la discriminación estética, donde lo blanco es lo sano, lo puro, digno de atención y cuidados. 
El sistema binario, divergente de la centralidad hegemónica, encuentra otros modos de reproducir y privilegiar el imaginario homogéneo de este territorio, al costo negativo de generar diferentes niveles de exclusión, marginación, discriminación, estratificación y jerarquización en los espacios restantes. Ahora se da paso a comentar otra valencia que emana de pensar el centro histórico como territorio moral.

\section{Lo blanco: frontera simbólica espacial y temporal}

El color aplicado a la arquitectura céntrica cumple también otra labor moral en el imaginario tradicional de Popayán. Lo blanco marca las fronteras territoriales de lo histórico con relación al espacio urbano diferenciado de la gramática y el discurso coloniales. Esta importante función simbólica consiste en servir de referente espacial, pues por medio del color la cartografía mental ubica el centro y lo establece como eje de poderes. Lo que guía, a su vez, los itinerarios del uso y la orientación de los rituales cotidianos que la gente practica en este sector, según la temporalidad del día o la noche. Gracias al color, en particular el blanco, el ciudadano genera procesos de reconocimiento social e identificación individual con un territorio específico, a través de la evocación e interiorización simbólica, que no dejan de percibirse como cargado de sacralidad urbana pese a la rutina y lo limitado de su espacialidad, bien por el aura religiosa de pureza que emana de la propiedad cromática, o bien por los sentidos de lo histórico escritos como tatuajes en la piel de la ciudad, al modo de lozas, placas, escudos y otros emblemas de la cultura heráldica con los cuales se inscribe la política de memoria tradicional. Es por medio de la textualidad arquitectónica que se marca interiormente el grado de filiación con Popayán. Y a partir de ello se construyen hábitos y nacen sentimientos urbanos de identificación y pertenencia, determinados por la condición moral del territorio.

Para el visitante la función orientadora del color blanco cumple un cometido distinto de la ordenación lograda luego del reconocimiento e interiorización del espacio. En principio, esta textualidad genera extravío, pues faculta más la pérdida que la debida ubicación. Parafraseando a Marc Augé (2000), podríamos referirnos al sector colonial como un "no lugar", pues la propiedad homogeneizante del color, con sus atributos y facultades miméticas, lo hace una textualidad que logra borrar toda diferencia, por ejemplo, de los variados estilos arquitectónicos de los edificios y monumentos, los cuales no revelan tanto las diferencias como sí las semejanzas creadas por la unificación cromática. Al visitante le resultan iguales las calles y fachadas. "El no lugar del blanco", a su vez, esconde la temporalidad ecléctica de lo histórico, y convierte este territorio en algo indiferenciado, donde la dificultad de marcar otra imagen en la mente, por medio del cuerpo o el habla, para hacerlo hábito, relato y memoria, es la acción simbólica cometida por las artes juveniles de hacer ciudad que se toman algunos lugares y crean la escenicidad propia de un territorio resignificado.

De igual manera, el color metaforiza el tiempo de la ciudad y, por tal propiedad, se interpreta esta valencia urbana a partir del relato ciudadano que expresa que lo histórico es blanco; en tanto que esta marca se revela como el mayor signo del pasado urbano; es decir, que todo aquello que no es blanco se mantiene por fuera de la frontera temporal y, por su efecto, se convierte en región moral de privilegio social y distinción cultural. 
De tal suerte que la gente sabe, acaso de modo inconsciente, que hay historia donde está lo blanco, y en el lugar donde éste acaba empieza la ciudad diferencial de la tradición hispana, lo cual configurará la cartografía tradicional de lo imaginario, para dar identidad al territorio urbano bajo el apelativo interpelado, ahora con la propiedad mimética del color.

\section{Popayán: el rostro jánico y su máscara colonial}

Si con la aplicación cíclica del color único, el blanco predominante del casco viejo, la ciudad restaura su aura hispánica religiosa y colonial, también el espíritu conservador que ordena los signos se renueva mediante el efecto del tiempo recobrado, conservado y detenido en el cromatismo uniforme de la evocación temporal, con lo cual Popayán hace que la historia viva en el presente, hasta desbordarlo. De tal suerte que esto logra anclar, una vez más, la identidad contemporánea en el imaginario tradicionalista, sin dar espacio a que la diferencia se exprese igual o sea reconocida a nivel social como forma lingüística complementaria de la diglosia urbana. La forma recíproca en que tradición cultural y poder se nutren y afirman, posibilita que no muera el mito de la arcadia, y por el contrario, genere sentimientos renovados de antigüedad e inmortalidad, bajo el simulacro del ser histórico sagrado que cubre u oblitera el sentido de realidad moderno en su viejo ropaje.

Por lo arriba expuesto, Popayán exhibe el lado luminoso del rostro jánico contrahecho, de una ciudad escindida entre centro histórico y sectores periféricos. Es la máscara del color en las fachadas, cuya piel blanca se ha vuelto una denominación de origen, lo que faculta el privilegio del reconocimiento de su imagen y hace del tiempo el simulacro o apariencia de una vejez mayor de la real. Cuando los frontis encalan sus fachadas, diversas en épocas y estilos, la ciudad contemporánea vuelve de nuevo a ser antigua. Así, la Popayán de hoy torna a su preciada infancia, al comienzo del relato que inventara para retrotraer hacia el presente el siglo XVI en las calles del XXI, y crear la ilusión complaciente, el espejismo seductor de ver un asunto histórico en cada piedra, adoquín o muro del Centro.

Se ha señalado que la trama de las formas se esconde en la propiedad mimética de lo blanco uniforme y homogeneizante de la diversidad arquitectónica, por lo cual desaparece todo signo de la diferencia, al punto que el matiz del detalle barroco monumental, por ejemplo, también está oculto en el color de la imagen urbana totalizante de la identidad cultural contemporánea.

Lo anterior no impugna el grado de autenticidad histórica que poseen algunas edificaciones religiosas y civiles, aun cuando la restauración e intervención atenúe significativamente el valor a tasar, como monumentos expuestos al deterioro de la lesión humana o natural, sino que busca poner en situación la manera como el imaginario colonial contemporáneo, a través del procedimiento simbólico analizado, logra generar realidades ilusorias y sentidos de verdad legítimos. La ostentosa máscara de antigüedad, junto a la apariencia de inmortalidad renovada y el simulacro incólume de sacralidad, se imponen en la textualidad urbana con su fuerza imaginaria y generan la saturación cultural del centro como imagen única y total de Popayán, ocasionando con ello los fenómenos de marginación, exclusión, jerarquización y estratificación del conglomerado social, antes mencionados. 
Adicional a estas lecturas, otros procesos de encubrimiento se encuentran como valencia del color blanco en Popayán, los cuales se exponen con el consecuente juicio crítico.

\section{Simetría del espacio vertical y desigualdad social}

Si bien el color blanco acentúa la simetría urbana del trazado geométrico clásico de damero, conformado por una retícula ortogonal de calles orientadas hacia los cuatro puntos cardinales (Téllez, 1998, pág.40), el cálculo estratificador inicial no deja de ejercer la fuerte jerarquización simbólica de una ciudad inclinada al silencio, cuya habla central reproduce la voz monocorde de un discurso exclusivo y excluyente de la diversidad social y la diferencia cultural actuales.

En tal sentido, la ciudad del romance y el idilio evocados es la Popayán adánica que inventara el relato histórico decimonónico de Jaime Arroyo (1955), cuando imaginó la expedición de Juan de Ampudia como el encuentro con un paraíso natural e identificó en ello el nacimiento de un pacto vigente todavía, fundado en la relación armónica entre el trazado original simétrico y el sentido de igualdad social, derivado a la vez del repartimiento equitativo de sus manzanas, cuadras y solares. $\mathrm{Al}$ respecto, cabe recordar que la división matemática de este territorio permitió idealmente una distribución de predios de estricta equivalencia para todos sus poseedores (Téllez, 1998, pág.42), lo cual supone creer que antaño la ciudad fue escenario de clases en armonía sin acaso fijar asimetrías sociales, propio del deseo arcádico europeo, del mito mismo de la Arcadia colonial, de ver encarnado el Paraíso prometido en América. Aunque tampoco se deba olvidar que esta construcción fue endógena de una visión diferenciada del mundo hispano heredado por los élites criollas, primero; luego, por la sociedad republicana; $y$, ahora, la contemporánea, en vías de aperturar sus imaginarios y modernización urbana, herederos de una cartografía escindida por los prejuicios étnicos y de clase antes aludidos.

Dada la condición múltiple de atributos y propiedades de lo blanco, el efecto del color aquí vendría a tener una interpretación ambivalente, ya que de un lado esta textualidad urbana significa dar sustento material a la idea del orden social simétrico, y en apariencia igualitario, de la estructura religiosa que la rige bajo el sentido de equidad humana, lo cual busca encarnar la arcadia colonial como reino de Dios y establecer con ello la igualdad divina entre los hombres. Y de otra parte, lo blanco ejerce su fuerza estética homogeneizante y unificadora en la arquitectura uniforme central, que tanta atracción suscita en el ciudadano y el visitante, para hacer de la armonía vertical, esto elogiado como sentimientos de identidad, un instrumento simbólico de jerarquización, que a su vez tiene el poder adicional de ejercer discriminación de los sectores periféricos, bajo el efecto del "hechizo estético-religioso", del sosiego producido por la lentitud y levedad temporal de este territorio, a modo de vivir un estado de bienestar transitorio que redunda en una sensación de paz general, o bien en actitudes de confianza y seguridad particulares

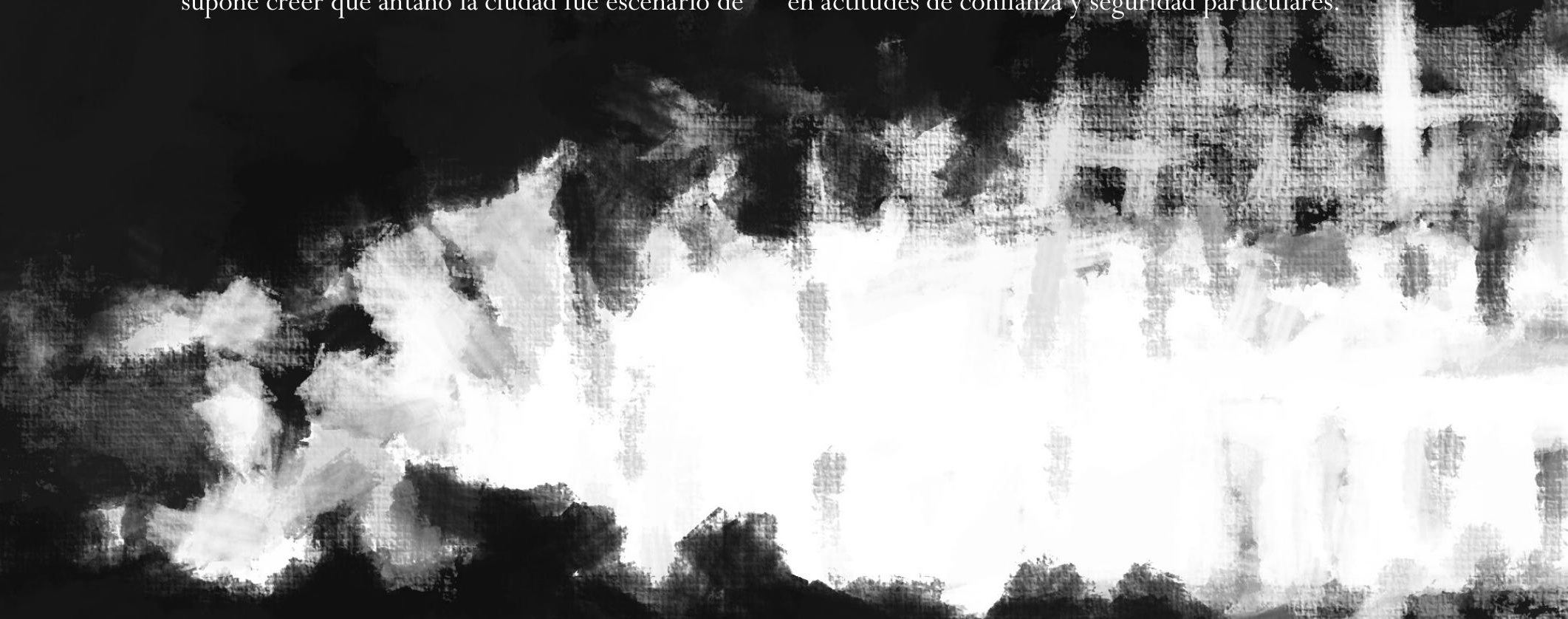




\section{Armonía entre naturaleza y arquitectura}

No siempre ocurre el feliz encuentro entre civilización urbana y naturaleza, por ello la empatía que suscita en Popayán la arquitectura actual del sector colonial con el paisaje natural ${ }^{16}$, se acentúa con las propiedades miméticas del color blanco. Valga recordar otra vez que uno de los factores de elección para fundar la ciudad española fue el ecosistema favorable en recursos naturales y clima. Desde el nacimiento de Popayán, la relación entre naturaleza y arquitectura no constituyó un campo de antagonismos, sino mejor de realidades complementarias, cuya unión hizo más armónico el sentido de lo bello, al punto de reforzar la reciprocidad simbólica de la homogeneidad urbana central, con las propiedades también estéticas del medio ambiente confortable y rico en medios. Lo estético artificial del patrimonio arquitectónico central establece con el entorno natural una fuerza mayor de tipo trascendente, dado que este atributo encuentra como dispositivo cultural un lugar privilegiado para manifestarse como expresión metafísica, ahora de índole artístico.
El modo como el color blanco contribuye a diluir la antinomia moderna de cultura/ naturaleza, consiste en el valor de síntesis que alcanza con la luz solar, por ejemplo, a la hora del crepúsculo, cuando la energía cromática hace ver el cielo como una pintura que sabe refractar con su intensa belleza en las calles y paredes blancas. Estos atributos plásticos los supo retratar de manera notable Efraim Martínez y cantar mejor Guillermo Valencia (1948, pág.666) en un poema de madurez, que a la letra reza: "Hay un instante del crepúsculo/ en que las cosas brillan más/ fugaz momento palpitante/ de una morosa intensidad". La síntesis entre luz celeste y color terrenal como metáfora urbana de Popayán, lleva a pensar en el valor estético que alcanza la ciudad para el imaginario colonial contemporáneo, por lo cual se convierte en objeto artístico asediado por la mirada que busca retratar en imágenes su belleza y descifrar en signos el misterio de su magia silente, bien a través de fotografías o de pinturas. A nivel cotidiano el arrobo estético es total. La contemplación del crepúsculo, por citar un caso, desde el morro de Tulcán es la respuesta vívida de la naturaleza bucólica que han recreado las ficciones poéticas del espíritu de Popayán.

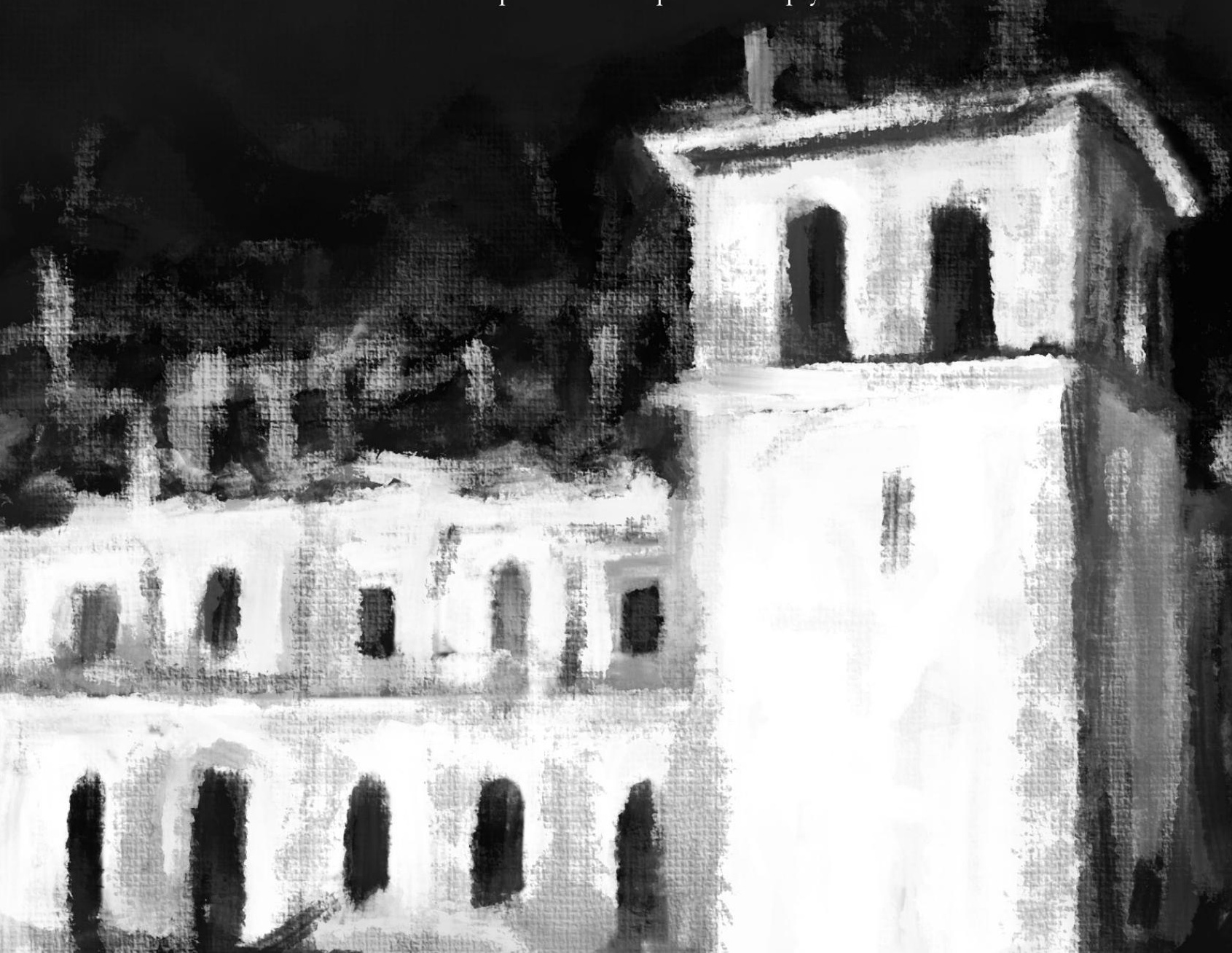


Sin embargo, este dispositivo cultural también ha detonado el problema de concentrar la representación artística de la ciudad en lo colonial, exclusiva al contorno monumental que muestra sólo edificaciones vacías de gente, lo cual hace extrañar el paisaje cotidiano habitado por el conglomerado social de voces, escrituras y memorias. En la otra orilla del rostro jánico de la Popayán bifronte se ubica el bullicioso suceder vital de unas periferias diversas en lenguajes y símbolos, cuya riqueza no la representan los lenguajes artísticos de la tradición como la fotografía, la pintura ni la literatura de encomio y poco aparece en la artesanía; todo ello agotado en pocos modelos y motivos, casi siempre de perfiles arquitectónicos baldíos y paisajes bucólicos. Lo exhibido, reiteramos, es la ciudad vacía, sin personas.

¿Será la Popayán fantasma de la representación tradicional y turística la que otorga identidad a los rostros vivos, en tanto que la voz presente no es más que la forma de un silencio insoportable de la mudez ante el pasado vuelto a reeditar, una y otra vez, mediante la actualización simbólica de los ritos litúrgicos, de la estética colonial expandida a otro lugares, para así instalar su orden y sentido de poder en el ahora del día a día que fluye en su propio tiempo y habla su propia lengua?

\section{Fotogénesis diurna y fantasmagoría nocturna}

La constelación simbólica (Durand, 1968) del color blanco analizada revela la convergencia de asuntos opuestos en su diversidad semántica, como es el ejercicio crítico de pensar esta textualidad en su positividad y negatividad. Para culminar esta reflexión se explora un poco el sentido positivo del color en dos valencias que surgen al momento de situarse en una perspectiva temporal de la cotidianidad urbana de Popayán.

Resulta claro que la identidad cultural urbana en la ciudad contemporánea da cuenta de un régimen diurno del imaginario colonial. Régimen que, situado en la simbólica ritual, es de trascendencia religiosa, pues persiste como fuerza humana el afán purificador de lo sagrado. Junto a la práctica letrada de ciudad universitaria y administrativa, a nivel cotidiano, Popayán está signada por la actividad laboral del préstamo de bienes y servicios en las jornadas oficiales de funcionamiento semanal, de lunes a viernes y en horarios estrictos de 8 a.m. a $12 \mathrm{~m}$, y de 2 a 6 p.m. Por fuera de la convención del trabajo que regula la vida social moderna, la ciudad colonial suspende casi todas sus dinámicas.

Y es allí, en la temporalidad diurna de lo vacío, donde el imaginario colonial se sitúa para ejercer la mirada del auto-reconocimiento estético de lo urbano, centralizado en las muestras fijas que realiza la fotografía arquitectónica de la ciudad blanca. La representación visual de las imágenes de mayor significado cultural, tomadas exclusivamente del patrimonio monumental tradicional, resultan emblemas de la identidad urbana contemporánea que pocas variantes ha tenido desde el establecimiento institucional como ciudad ilustre. Salvo las acciones de restauración e intervención monumental, ejercidas durante las tres últimas décadas, el panteón icónico de los símbolos urbanos que representan a la Popayán turística no ha sido renovado con otras imágenes y tampoco con lecturas valorativas distintas del elogio fortuito y de fácil comercio. 
La permanencia arquitectónica de Popayán en el mundo de la semejanza (Cfr. Foucault, 1968), y de la mismidad identitaria, es el motivo que le ha impedido a la ciudad abrir la mirada urbana hacia el reconocimiento y representación de la diferencia, de la otredad cultural. En la fotogénesis reside la operación doble de permanencia monumental y estabilidad de lo imaginario. Este ejercicio ciudadano del ver es un fenómeno que da cuenta del grado fotogénico de la ciudad callada, sin habitantes, cuya lengua habla sólo del pasado a los vivos con la fuerza expresiva de la ausencia que le otorga la estética colonial. Sin duda alguna, el resultado ha sido reforzar la condición natural de lo bello con la monumentalidad arquitectónica, humilde de formas y materiales, bajo la eficacia simbólica de una operación artificial que permite integrar estas fuerzas en una unidad de sentido como es la imagen visual de "Popayán ciudad blanca".

El intersticio que abre el cese capitalista del comercio material y simbólico en mitad del ruido de la ciudad diurna, que es de carácter abierto y público, es también tomado por la Popayán actual para instaurar allí el aura colonial. Por su parte, la ciudad nocturna se calla en la introspección de lo privado. Esta dinámica urbana se estima propia del legado cultural de Popayán como centro religioso colonial, lo cual lleva a que la experiencia de la aventura y la peripecia cotidiana sea algo vivido, pero de puertas para adentro. La arquitectura conventual de claustros y templos ha tatuado, por demás, el ser urbano con la reserva y sigilo inveterados

de mostrar sólo el rostro jánico de la ciudad de las fachadas.

De este gesto emerge un atributo poco explorado como relato urbano, digno de ocupar un lugar importante en la representación literaria o plástica de la ciudad contemporánea. Aunque haya sido registrado con solvencia estética por la fotografía, la ciudad nocturna conserva casi intacta su magia y misterio espectral, reservado como experiencia personal a la divagación y el diálogo íntimo de la noche. Incluso luego de haber sido intervenidos con focos luminosos algunos de los escenarios más emblemáticos de la gramática colonial y religiosa, que acentúan desde el piso el carácter protagónico monumental de actores vivos, todo como una puesta en escena más cotidiana de la ritualidad cultural de la ciudad tradicional.

Es el color blanco lo que hace posible la fantasmagoría nocturna de Popayán. Su construcción es dada también por la temporalidad estética del cromatismo monocorde que fascina con su espectro aurático revivido ante la contemplación, allí donde lo espectral del juego de luces y sombras da paso al poblamiento del vacío y el silencio inciertos por la verdad del rumor y el susurro que alcanzan a ser voz y camino para los pasos del transeúnte.

\section{Cierre}

En la polisemia del signo arquitectónico como textualidad urbana se encuentra la facultad para interpretar de otra manera las realidades ya significadas por el estatuto colonial urbano. A través de la representación simbólica del color se ha impuesto maneras exclusivas y particulares de ver el mundo desde la verticalidad dominante de la tradición hispánica; fenómeno que ha sido necesario poner en discusión. De tal modo que la metáfora urbana del color blanco, explorada aquí de modo crítico, da cuenta de la estructura y el sistema colonial imaginario con el cual la identidad urbana fundamenta sus sentidos y significados actuales. 


\section{Notas}

${ }^{1}$ Este artículo es resultado parcial del proyecto de investigación titulado "Identidad urbana y diferencia cultural. El estatuto colonial contemporáneo en Popayán”. Universidad del Cauca, Colombia. Código VRI ID 3694.

${ }^{2}$ Los documentos históricos ratifican que la traza original se ha mantenido en su lugar, por lo que las 20 cuadras iniciales son las mismas de la cuadricula española (Cfr. Velasco, 2004, págs.24-25).

${ }^{3}$ En un ejercicio de campo sobre la noción de "punto de vista ciudadano", realizado en Popayán por Armando Silva (1997, pág. 80), un informante sostiene que "alrededor del parque Caldas están los sitios de poder”. Aspecto que fuera corroborado mediante un ejercicio académico de aula con estudiantes de Comunicación Social de la Universidad del Cauca en 2012, acerca de la cartografía simbólica otra del territorio central.

${ }^{4}$ Durante los últimos años la Universidad del Cauca sufrió la censura del centro filial de monumentos que le impidió la construcción del edificio de la Facultad de Ciencias Contables, Económicas y Administrativas en la esquina de la carrera 4 con calle 5, argumentando que el diseño arquitectónico se apartaba del presunto y pretendido "estilo Popayán".

${ }^{5}$ En el caso del lenguaje audiovisual, destacamos el trabajo de Carlos Illera (1991) con "Occidente” y el largometraje en video "Marcando calavera" de Nelson Osorio (1999), los cuales abordan problemas sociales en la comuna 7 de Popayán; donde se ubican muchos de los barrios creados a partir de invasión de predios a raíz de la crisis de vivienda que produjo el terremoto del 31 de marzo de 1983. En la narrativa de ficción y periodística, la novela "Oscuro por claritas” y el libro "14 crónicas” de Marco Valencia Calle (2002, 2000) representan la incorporación de la otra Popayán, mediante la estilización del habla popular.

${ }^{6}$ Juan López de Velasco (citado por Téllez, 1998, pág.44) refiere que a fines del siglo XVI, a escasas tres décadas de la fundación, la población de Popayán "es un pueblo de treinta vecinos españoles, los diez y seis encomenderos: hay en su comarca treinta y dos pueblos o parcialidades de indios, en que hay como nueve mil indios [...] repartidos en diez y nueve repartimientos [...]".

${ }^{7}$ Sin duda, el emblema icónico de esta configuración cultural es la pintura "Apoteosis de Popayán" de Efraim Martínez, donde la sociedad estratificada de la ciudad está regida por la práctica religiosa, en un escenario urbano ideal de sí mismo e idealizante del contexto que despotiza la historia, ya que la tensión y el conflicto son obliterados de la representación plástica.

${ }^{8}$ El centro histórico de Popayán fue declarado Monumento Nacional mediante la Ley 163 de 1959. De igual modo, la norma 397 de agosto 7 de 1997 o Ley de Cultura, amplió la cobertura de protección a los bienes monumentales públicos.

${ }^{9}$ Ya se aludió a la Semana Santa como el más importante ritual de convergencia ciudadana. Sobre el significado cultural que adquiere, luego de 450 años de celebración casi ininterrumpida, resulta oportuno traer la reflexión del fenómeno que Gustavo Wilches (1999, pág. 25) ofrece cuando sostiene que se trata del único acontecimiento "capaz de inspirar colectivamente sentimientos de identidad, de pertenencia, de significado, de trascendencia, de continuidad y propósito".

${ }^{10}$ Con respecto a las medidas gubernamentales que regulan la textualidad monocromática, y luego publicitaria del sector colonial y el centro histórico, remitimos al balance crítico que ofrece Javier Velasco Mosquera (2004, págs. 143-210) de las propuestas de conservación y criterios de restauración de estos sectores, diseñados inicialmente por el arquitecto Eladio de Valdenebro y Jaime Salcedo. Sobre la normatividad que privilegia el empleo de la cal blanca, leemos en la tipología del color que: "todos los repellos sean de boñiga o de cemento rugoso que recubren muros y aleros, deben ser pintados en blanco, pero de cal. Nunca en vinilo”.

${ }^{11}$ Resulta oportuno señalar también que el cromatismo colonial era diverso, aunque la cal era el material que aún hoy día se aplica. Los tonos claros de azul y amarillo han sido incorporados al estilo urbano tradicional contemporáneo.

${ }^{12}$ Utilizamos este término griego en el sentido primero dado por Parménides (citado por Ferrater Mora, 1994, pág.936) cuando presenta la doctrina de la opinión como apariencia, ilusión o engaño.

${ }^{13}$ El fotógrafo Luis H. Ledezma (2012:8) lo testifica: "Por supuesto, ¡yo conocí en carne propia las niguas!Y lo digo a mucho honor, porque "patojo que se respete debe saber cuánto rasca una nigua”. Y es que ese diminuto animalito se ubicaba en medio de los dedos o entre la uña y la carne, ponía sus huevos y mientras éstos se incubaban, la rasquiña que producía era insoportable. Hasta el grado de que el andar se dificultaba y precisamente de ahí proviene el mote que tenemos los "patojos”, porque "patojo" significa ser nigüento". 
${ }^{14}$ En el libro del Apocalipsis, afirma Cirlot (1981, pág. 101), "el blanco es el color del vestido de los que 'han salido de la gran tribulación, han lavado su ropa y la han blanqueado con la sangre del Cordero'. Jesús como Juez, agrega, es presentado con cabellos blancos 'como la blanca lana'. La blancura, concluye el autor, simboliza el estado celeste".

${ }^{15}$ Valga recordar al respecto que la crisis teológica del siglo XVI fue ocasionada por la razón científica de Copérnico, mediante su descubrimiento de la rotación planetaria que logra desplazar la centralidad del universo regido por Dios, a un mundo infinito y sin embargo unitario controlado por el hombre. Del desencanto inicial se toma confianza y conciencia para comprender el Universo y creer vencer la naturaleza. Al final de este desarrollo, afirma Arnold Hauser (1976, pág. 102), en lugar del temor al Juez Supremo aparece el "estremecimiento metafísico" que alimenta el arte barroco.

${ }^{16} \mathrm{Al}$ respecto de este asunto, Germán Téllez (1998, pág.42) afirma que "la retícula de calles de Popayán no fue una imposición forzada sobre el terreno escogido, sino un ajuste suave y ceñido al terreno y al paisaje circundante".

\section{Referencias}

Arroyo, Jaime (1955). Historia de la Gobernación de Popayán. Tomos I y II. Ministerio de Educación Nacional, Ediciones de la Revista Bolívar, Bogotá.

Augé, Marc (1992). Los “no lugares”. Espacios del anonimato. Una antropología de la sobremodernidad.

Barcelona, Gedisa.

Barrie, J. M. (1987). Peter Pan. Alianza Editorial, Madrid.

Bourdieu, Pierre (1991). El sentido práctico. Siglo XXI, Madrid.

Cassirer, Ernst (1998). Filosofía de las formas simbólicas. Tomo III. Fondo de Cultura Económica, México.

Castoriadis, Cornelius (1982). La institución imaginaria de la sociedad. Tusquets, Barcelona.

Castrillón, Diego (1972). Estilo Popayán. Editorial López, Popayán.

De Certeau, Michel (2000). La invención de lo cotidiano. 1. Artes de hacer. Universidad Iberoamericana, México.

Cirlot, Juan-Eduardo (1981). "Blanco”, en: Diccionario de símbolos. Editorial Labor, Barcelona. pp. 101-102.

Durand, Gilbert (1968). La imaginación simbólica. Amorrortu Editores, Buenos Aires.

Ferrater Mora, José (1994). Diccionario de filosofía. Tomo 1. Editorial Ariel, Barcelona.

Foucault, Michel (1968). Las palabras y las cosas. Siglo XXI Editores, México.

García Quintero, Felipe (2006). “Popayán en su literatura”. En: Popayán 470 años. Letrarte,

Bogotá. pp. 120-145.

Hauser, Arnold (1976). “El barroco”. En: Historia social de la literatura y del arte. Tomo 2. Editorial Labor.

Punto Omega, Barcelona. pp. 91-151.

Illera Benavides, Carlos (1991). Occidente. Video argumental. Fundefilms, Popayán.

Ledezma, Luis H. (2012). Fotos de Popayán. Ediciones Popayán Positiva, Popayán.

Osorio, Nelson (1999). Marcando calavera. Largometraje. Fundefilms, Popayán.

Rama, Ángel (1984). La ciudad letrada. Ediciones del Norte, Hanover.

Romero, José Luis (1976). "Las ciudades hidalgas de indias". En: Latinoamérica: las ciudades y las ideas.

Siglo XXI, México. pp. 59-118.

Saldarriaga, Alberto (1985). Los colores de la calle. Carlos Valencia Editores, Bogotá.

Silva, Armando (1997). Imaginarios urbanos. Cultura y comunicación urbana. Tercera edición aumentada. Tercer Mundo Editores, Bogotá.

Téllez, Germán (1998). “Aspectos urbanísticos”. En: Popayán. Guía histórica. Ministerio de Cultura, Bogotá. pp. 40-58.

Valencia, Guillermo (1948). Obras poéticas completas. Segunda edición. Aguilar, Madrid.

Valencia Calle, Marco Antonio (2000). Oscuro por claritas. Editorial Trueque, Popayán. (2002) 14 crónicas. Edición de autor, Popayán.

Velasco Mosquera, Javier (2004). “La normatividad en el sector histórico de Popayán”. En: Consideraciones sobre la arquitectura en Popayán. Editorial Universidad del Cauca, Popayán. Pp. 143-210.

Wilches-Chaux, Gustavo (1999). “Las procesiones de Popayán: un sentimiento colectivo”. En: Semana Santa en Popayán. Villegas Editores, Bogotá. pp. 25-107.

Recibido: octubre 30 / Aprobado: noviembre 25 de 2013 